\title{
Development of Professional Skills in the Context of Higher School Dual Education
}

\author{
https://doi.org/10.3991/ijet.v16i10.19373 \\ Nursaule Tastanbekova ${ }^{(凶)}$, Bahyt Abenova, Maral Yessekeshova, \\ Zhanar Sagaliyeva, Gulmira Abildina \\ S. Seifullin Kazakh Agro Technical University, Nur-Sultan, Kazakhstan \\ nursaule.84@mail.ru
}

\begin{abstract}
The article considers aspects of the dual education system which are implemented in advanced higher education institutions of the Republic of Kazakhstan. The ranking of the best universities for the implementation of the dual education system is analyzed within the framework of previous studies on the matter. It is noted that in the system of dual education a significant role is given to the formation of the personality of the specialist. It is emphasized that dual education is aimed at raising awareness of students' educational and professional activities. The main competences of the student at different levels (practical training, content and structure of educational programs, level of mutual trust, level of adaptation to the work process, level of learning motivation, level of precision in understanding the profession, level of standardized training) are described. The importance of practical orientation of the education system based on acquired competences (solving real production problems, reforming research work, participation in scientific and practical conferences) is emphasized. Recommendations on the process of introducing dual education are provided and models for classification of professional development resources, components of conceptual model, principles of formation of the structure and content of the educational programs, indicators of professional skills and ones' development are offered.
\end{abstract}

Keywords - Competences, cooperative learning, dual education, educational models, macro environment, vocational education

\section{Introduction}

The modern world economic space is actively seeking and introducing the most prestigious technological processes in all industries. Investments in the technological upgrading of their enterprises are absolutely justified because the introduction of new technologies into the world production confidently expands and monopolizes the market of sales, increases the volume of its production, lowers logistic costs and increases its profit, justifying its investments in new technologies. The labor market responds immediately to the needs of commodity producers by offering vacancies driven by a broad set of competency requirements for its participants.

The problem of modern education is the separation of theoretical knowledge that a student receives in higher education and from the industrial reality that young people 
face after graduation. Even the most talented student is not ready to tackle the challenges that new work poses to one. This is due to the fact, that the theory, taught in high school, always remains only a set of terms and formulas, if it does not correspond to practice. In the recent years, with a gradual expansion of information economy model to developing countries, the problem has become more urgent due to the constant adoption of new technologies as a requirement at all career levels [1]. Therefore, it is a primal necessity to eliminate the lack of connection between theory and practice, as well as to help the students to develop their emotional intellect (leadership and communicative skills), which is also possible only through practice-oriented education [2]. Another important aspect is the opportunity to gain intercultural communication competence [3] when learning from foreign professionals (including the gradually developing digital communication inside the corporations).

Thus, the vocational education system is mobilized. In order to update its directions, it is necessary to introduce substantive aspects of education provision, that is, to update the content of practice-oriented educational process, focusing on the effective content of competences, which puts educational organizations in a difficult situation that does not allow to respond adequately and quickly to changes that are coming forward specialists [4]. This has long been addressed by European higher education institutions, which offer an effective way of training young highly qualified professionals, namely the introduction of a dual training system.

Dual training is one of the most successful models of cooperative learning and practice. It is a system in which students spend part of their study time at the production where they will work: in parallel with the academic studies, they go to a specific company or firm, where they gain practical experience (vocational training). Thus, the theoretical knowledge gained is supported by practical work in the enterprise.

The theoretical and practical aspects of dual education systems have been studied theoretically and practically by a number of scholars. F. Hermann, C. Korunka, M. Lueger and D. Weismeier-Sammer [5] studied an intrapreneurship education in the dual education system. M. Bakator, S. Borić, D. Radosav and G. Radić [6] presented an innovative model of dual education through student-organization networks.

K. Oganisjana, A. Svirina, S. Surikova, G. Grīnberga-Zālīte and K. Kozlovskis [7] studied the problem of engaging universities in social innovation. M. Gessler and S. Peters [8] worked on the study of implementation of dual training programs through the development of boundary objects. J. L. Goeke, K. J. Mitchem and K.R. Kossar [9] wrote about redesigning special education teacher preparation: challenges and solutions. O. V. Galustyan, V. A. Kirik and N. Mazáčová [10] analyzed how the preparation of future teachers benefits from the partnership between universities and schools via project activities during students' pedagogical practice, with the university assuming the role of mentor. V. Spasenović [11] analyzed implementation possibilities, prerequisites and challenges of the dual education system. O. Valiente and R. Scandurra [12] reviewed challenges to the implementation of dual apprenticeship in OECD Countries.

F. S. Azevedo [13] offered an inquiry into the structure of situational interests. The state of dependence of economy and business on dual education was described by $\mathrm{M}$. Bogdanović, M. Vetráková and S. Filip [14]. The results of dual education were characterized by M. Boroš, A. Vel'as, K. Kampová and T. Loveček [15]. 
M. M. Alajmi [16] proposed to analyze the impact of E-portfolio use on the development of professional standards and life skills of students an algorithm for forming an individual trajectory of learning in the distance learning system. L. DarlingHammond, L. Flook, C. Cook-Harvey, B. Barron and D. Osher [17] wrote about implications for educational practice of the science of learning and development. L. Didukh, R. Gurevych, M. Kademija and V. Kobysia [18] presented an experience of preparation of competitive specialists in the conditions of the implementation of dual education in high education institution. N. Kulalaieva and S. Leu [19] described the work-based learning involving the dual education elements. S. Wichitsathian and D. Nakruang [20] worked on knowledge integration capability and entrepreneurial orientation. Comparative characteristics of dual education at different universities are presented in the works of M. Pogatsnik [21] (general and economical analysis); K. H. Hahn and A. Puksas [22] (Lithuanian and South Korean universities); J. Belas, B. Gavurova, M. Cepel and A. Kotaskova [23] (Slovak University); and O. Fatoki [24] (South Africa).

The implementation of dual education in Kazakhstan started in 2013 and proved itself successful. Scientists have identified industries with a small number of staff (agriculture, transport, metallurgy and mechanical engineering, oil and gas and chemical production), and educational institutions where they can prepare. To date, an organization has been set up in the country to carry out and coordinate work in this area (Dual Training System Methodology Department), develop typical curricula and educational programs in specialties, the novelty of which is that more than $40-50 \%$ of study time is spent on production practice.

Starting from 2020, it is planned to reimburse the mentors involved in the training of personnel for dual training, their expenses on the remuneration of the mentor, expenditures within the framework of per capita financing at the expense of the state educational order. In order to improve the quality of training with technical education and professional, post-secondary education will be introduced the mutually beneficial stakeholder partnerships (networked education, industry clusters, patronage of large and medium-sized business entities over schools, student relations) [25].

The relevance of the research is determined by the complex problem of the modern system of vocational education in Kazakhstan and other states striving to be among developed countries - the question of the mismatch of knowledge caused by a situation when the demand for educational services is formed by their direct consumers instead of employer companies or government [26]. Employers express a high need for competent and socially mobile professionals, adaptable to non-standard conditions. In order to provide this kind of preparation and close the gap between theory and practice, the system of dual education in higher education institutions is used.

\section{Materials and Methods}

Our study implements theoretical analysis of the dual education system based on information analytics of advanced higher education institutions of the Republic of Kazakhstan [27], as well as two major documents in the legislative system of Kazakhstan concerning the dual education system: Decree of the Government of the Republic of Kazakhstan dated December 27, 2019 No. 988 “On approval of the State program 
for the development of education and science of the Republic of Kazakhstan for 2020 - 2025" [28] and Order of the Minister of Education and Science of the Republic of Kazakhstan dated January 21, 2016 No. 50. "On the approval of the Rules for the organization of dual training" (as amended on September 11, 2018) [25].

\section{Results}

Using the national rating, we have selected the best universities in Kazakhstan for their annual ranking to analyse. This information has helped us to summarize the process of introducing a dual education system in the country and to develop recommendations for universities that are planning to implement it. Table 1 shows how dual education is used in Kazakhstan leading multidisciplinary universities.

Table 1. Dual education at the best multidisciplinary universities in Kazakhstan

\begin{tabular}{|c|c|c|}
\hline University & The procedure for proceeding & Partners \\
\hline $\begin{array}{l}\text { Al-Farabi Kazakh } \\
\text { National University }\end{array}$ & $\begin{array}{l}\text { In programs the overwhelming amount of credit } \\
(\sim 90 \%) \text { is allocated to the professional block of } \\
\text { disciplines, which, in turn, consists of the STEM- } \\
\text { forming module (STEM - Science, Technology, } \\
\text { Engineering, Mathematic), basic professional } \\
\text { (mandatory) modules, the module of individual } \\
\text { educational trajectories and an interdisciplinary } \\
\text { module. At the same time, only } 25 \% \text { of credits } \\
\text { are allocated to the elective modules of individu- } \\
\text { al educational trajectories, which allows to } \\
\text { increase the basic vocational training. }\end{array}$ & TarGPI and NIS (Taraz) \\
\hline $\begin{array}{l}\text { L.N. Gumilyov } \\
\text { Eurasian National } \\
\text { University }\end{array}$ & $\begin{array}{l}\text { Dual education at university was introduced in } \\
\text { the specialty "5V071700 - Heat Power Engineer- } \\
\text { ing". During the entire academic year, students of } \\
2,3 \text { and } 4 \text { years are taught one by one, first at the } \\
\text { university and then at the production. One of the } \\
\text { courses is obligatory to be done at the enterprise } \\
\text { or university: for example, in September students } \\
\text { of } 2 \text { and } 4 \text { years are taught at the enterprise, and } \\
\text { of year } 3 \text { - at the university, and in October they } \\
\text { change places. }\end{array}$ & $\begin{array}{l}\text { A corporation of Eurasian Energy } \\
\text { Corporation JSC, which is a part of } \\
\text { ENRC }\end{array}$ \\
\hline $\begin{array}{l}\text { E.A. Buketov Kara- } \\
\text { ganda State Univer- } \\
\text { sity }\end{array}$ & $\begin{array}{l}\text { Dual training in the specialty "Transport, } \\
\text { transport technology and technology". Over the } \\
\text { past } 3 \text { years, about } 1500 \text { grants have been award- } \\
\text { ed by the state in this specialty. }\end{array}$ & $\begin{array}{l}\text { Agromashholding JSC Sary-Arka } \\
\text { Autoprom LLP (Kostanay), Ka- } \\
\text { zakhstan Carriage Building Com- } \\
\text { pany LLP and Tulpar-Talgo plant } \\
\text { (Astana), Pavlodar Machine- } \\
\text { Building Plant JSC. Network } \\
\text { cooperation agreements have been } \\
\text { drawn up with Agromashholding } \\
\text { JSC and Sary-Arka Avtoprom LLP } \\
\text { (Kostanay). }\end{array}$ \\
\hline $\begin{array}{l}\text { M. Auezov South } \\
\text { Kazakhstan Univer- } \\
\text { sity }\end{array}$ & $\begin{array}{l}\text { The university created educational-scientific- } \\
\text { industrial complexes (USIC) on basis of leading } \\
\text { industrial enterprises of the country, with modern } \\
\text { technological equipment and the help of leading } \\
\text { specialists. }\end{array}$ & $\begin{array}{l}\text { KazFosfat LLP, Petro Kazakhstan } \\
\text { Oil Product LLP, Shymkentcement } \\
\text { JSC, Melange LLP, Ontustik } \\
\text { Munai Gas LLP, etc. }\end{array}$ \\
\hline
\end{tabular}


Table 2 demonstrates the implementation of dual education at the Kazakhstan technical universities.

Table 2. Dual education at the best technical universities in Kazakhstan

\begin{tabular}{|c|c|c|}
\hline University & The procedure for proceeding & Partners \\
\hline Satbayev University & $\begin{array}{l}\text { Dual training program "Construction". In the first stream of } \\
\text { dual education, builders are trained (already have practical } \\
\text { experience, but do not have a higher technical education). } \\
\text { Office workers with higher education are trained in other } \\
\text { specialties but are planning to work in the construction } \\
\text { industry in the future. Also, under this program, employees } \\
\text { with secondary specialized education (college) can study, } \\
\text { although the term of study will not be two, but three years. }\end{array}$ & BI-GROUP \\
\hline $\begin{array}{l}\text { Kazakh-British } \\
\text { Technical University }\end{array}$ & $\begin{array}{l}\text { Dual system of education is based on the principle of } 30 \% \\
\text { theory } 170 \% \text { practice. }\end{array}$ & $\begin{array}{l}\text { Oil refineries in Kazakh- } \\
\text { stan (Atyrau Refinery, } \\
\text { Petroleum Refinery, } \\
\text { PetroKazakhstan), } \\
\text { Romania (RomPetrol), } \\
\text { etc. }\end{array}$ \\
\hline $\begin{array}{l}\text { Karaganda State } \\
\text { Technical University }\end{array}$ & $\begin{array}{l}\text { Constant interaction with the enterprises that are part of the } \\
\text { corporate university ensures the internship of students with } \\
\text { their subsequent employment at the same enterprises. } \\
\text { Considering the requirements of specific industrial enter- } \\
\text { prises and involving their production base, continuous } \\
\text { systematic work with enterprises gives positive results in } \\
\text { terms of training specialists. At the same time, the need for } \\
\text { specialists at the enterprises of the region for 2014-2019, } \\
\text { confirmed by agreements, is } 3123 \text { people. }\end{array}$ & $\begin{array}{l}1007 \text { employment con- } \\
\text { tracts were concluded } \\
\text { with } 80 \text { enterprises of } \\
\text { Central Kazakhstan. } \\
\text { Over the past five years, } \\
\text { KSTU has trained and } \\
\text { employed } 1096 \text { special- } \\
\text { ists at existing facilities } \\
\text { in the Karaganda region } \\
\text { alone. }\end{array}$ \\
\hline
\end{tabular}

Table 3 summarizes how dual education is represented in the humanities and economic field.

Table 3. Dual education at the best humanities and economics universities in Kazakhstan

\begin{tabular}{|c|c|c|}
\hline University & The procedure for proceeding & Partners \\
\hline KIMEP University & $\begin{array}{l}\text { Considering the key trends in the } \\
\text { transport and logistics industry, the prob- } \\
\text { lems and realities of staffing requirements } \\
\text { in regional labour markets, the quality of } \\
\text { training for the transport and logistics } \\
\text { industry and the interaction of employers } \\
\text { with educational institutions with qualifi- } \\
\text { cations of specialists were discussed. }\end{array}$ & $\begin{array}{l}\text { JSC NC KTZ - "Centre for the assess- } \\
\text { ment and development of railway } \\
\text { personnel"; Air Astana JSC; NMSK } \\
\text { Kazmortransflot JSC; JSC "Kaz- } \\
\text { temirtrans"; SCAT Airlines JSC; RSE } \\
\text { "Aktau International Sea Trade Port"; } \\
\text { Kaztranservis JSC, Lokomotiv JSC, } \\
\text { Globalink Logistics Group. }\end{array}$ \\
\hline $\begin{array}{l}\text { Karaganda Economic } \\
\text { University of Kazpo- } \\
\text { trebsoyuz }\end{array}$ & \multicolumn{2}{|c|}{ The information is recorded only in colleges run by the university. } \\
\hline $\begin{array}{l}\text { Almaty Management } \\
\text { University }\end{array}$ & $\begin{array}{l}\text { The university provides training for } \\
\text { specialists in the educational program of } \\
\text { the specialty "5B050600 - Economics". } \\
\text { Students in the learning process use the } \\
\text { following software products and pro- } \\
\text { gramming languages: SPSS, Statistica, R, } \\
\text { Python, MS Project, MS Power Query, }\end{array}$ & $\begin{array}{l}\text { Raimbek Bottlers LLP, LLP "Danone } \\
\text { Berkut", LLP "Kazakhstan Carriage } \\
\text { Building Company", KazAtomProm } \\
\text { JSC, Almaty Heating Networks LLP, } \\
\text { KEGOC JSC, Foodmaster LLP, Kosta- } \\
\text { nay Minerals JSC, JSC FRP "Damu", } \\
\text { Aksay nan LLP, Eurasia Food Corpora- }\end{array}$ \\
\hline
\end{tabular}




\begin{tabular}{|l|l|l|}
\hline MS Power Pivot, MS Power BI, 1C, & tion JSC, Alma Tses LLP, JSC NK \\
Project Expert, Audit Expert. & "Kazakhstan Temir Zholy", Air Astana \\
& JSC, LP "Promtehservis Kazakhstan", \\
Aydin LLP confectionery company, \\
JSC "KazTransGas", Kazpost JSC, JSC \\
"KEGOC", Maslodel LLP, Sinooil LLP \\
and others.
\end{tabular}

Table 4 shows the programs introducing dual education at the art universities.

Table 4. Dual education at the best art universities in Kazakhstan

\begin{tabular}{|l|l|l|}
\hline \multicolumn{1}{|c|}{ University } & \multicolumn{1}{|c|}{ The procedure for proceeding } & \multicolumn{1}{c|}{ Partners } \\
\hline $\begin{array}{l}\text { Kazakh National } \\
\text { University of Arts }\end{array}$ & $\begin{array}{l}\text { The possibility of introducing "dual education" for one of } \\
\text { the largest departments of the university - the department } \\
\text { of "Acting Art and Director", namely for the training of } \\
\text { specialists in a unique profession: drama theatre actor and } \\
\text { director. In the specialty 5B040700 Acting, only 5\% is } \\
\text { allocated to the share of professional practice. For the } \\
\text { second year, 50\% of the time is freed for teaching practi- } \\
\text { cal subjects in the specialty and service subjects (in total). } \\
\text { The main problems begin in 3-4 courses. }\end{array}$ & $\begin{array}{l}\text { Future actors who have } \\
\text { learned the basics of } \\
\text { acting in the first two } \\
\text { years, most unjustifiably } \\
\text { remain in the same student } \\
\text { audiences. Work on the } \\
\text { role, on the play, takes } \\
\text { place in a virtual format. }\end{array}$ \\
\hline $\begin{array}{l}\text { Kazakh National } \\
\text { Academy of Chore- } \\
\text { ography }\end{array}$ & There is no official information. \\
\hline
\end{tabular}

Table 5 shows how dual education is currently used in medical universities.

Table 5. Dual education at the best medical universities in Kazakhstan

\begin{tabular}{|l|l|l|}
\hline \multicolumn{1}{|c|}{ University } & \multicolumn{1}{|c|}{ The procedure for proceeding } & \multicolumn{1}{c|}{ Partners } \\
\hline $\begin{array}{l}\text { Asfendiyarov Kazakh } \\
\text { National Medical Uni- } \\
\text { versity }\end{array}$ & $\begin{array}{l}\text { The decision of the management of KazNMU to } \\
\text { transfer interns to a practice-oriented system of } \\
\text { education in the internship has been made for about } \\
5 \text { years already. By now students have fully been } \\
\text { studying the general subjects, acquiring basic } \\
\text { knowledge in the specialty, also they have a founda- } \\
\text { tion in the core disciplines that form the professional } \\
\text { knowledge and skills. }\end{array}$ & $\begin{array}{l}\text { The practical training bases } \\
\text { are more than 23 medical } \\
\text { institutions of the Republic } \\
\text { of Kazakhstan and 7 medi- } \\
\text { cal institutions of the } \\
\text { Almaty region. }\end{array}$ \\
\hline $\begin{array}{l}\text { Semey Medical Universi- } \\
\text { ty }\end{array}$ & $\begin{array}{l}\text { At the level of the medical baccalaureate. Summer } \\
\text { professional practices are also provided, however, } \\
\text { their volume is insufficient for the quality training of } \\
\text { the future doctors. }\end{array}$ & $\begin{array}{l}\text { There is no official infor- } \\
\text { mation. }\end{array}$ \\
\hline
\end{tabular}

Finally, Table 6 summarizes the implementation of dual education at the leading Kazakhstan pedagogical universities. 
Table 6. Dual education at the best pedagogical universities in Kazakhstan

\begin{tabular}{|c|c|c|}
\hline University & The procedure for proceeding & Partners \\
\hline $\begin{array}{l}\text { Abai Kazakh Na- } \\
\text { tional Pedagogical } \\
\text { University }\end{array}$ & $\begin{array}{l}\text { In 2018-2020, the State budget grant project of the } \\
\text { "Migilik el" foundation (education of the XXI century, } \\
\text { fundamental and applied research in the humanities) was } \\
\text { won on the topic AR05134253 - "Dual-oriented educa- } \\
\text { tion as a condition for improving the professional training } \\
\text { of the future teacher". In 2018-2019 first-year undergrad- } \\
\text { uates of the specialty 6M010300-Pedagogy and Psychol- } \\
\text { ogy were introduced to the subject "Integration of the } \\
\text { activities of a school-college-university". In the academic } \\
\text { year } 2018-2019 \text {, the subject "Fundamentals of dual train- } \\
\text { ing" was introduced for the specialty 5B010200- } \\
\text { Pedagogy and elementary education; and in the specialty } \\
6 \text { D010500-Defectology - the subject "Dual training in the } \\
\text { training of defectologists". }\end{array}$ & $\begin{array}{l}\text { There is no official infor- } \\
\text { mation. }\end{array}$ \\
\hline $\begin{array}{l}\text { Kazakh National } \\
\text { Women's Teacher } \\
\text { Training University } \\
\end{array}$ & $\begin{array}{l}\text { Intensification of work on the introduction of programs of } \\
\text { additional and dual education. }\end{array}$ & $\begin{array}{l}\text { There is no official infor- } \\
\text { mation. }\end{array}$ \\
\hline $\begin{array}{l}\text { Kostanay State } \\
\text { Pedagogical institute }\end{array}$ & $\begin{array}{l}\text { Curricula have been developed for the educational pro- } \\
\text { grams "Informatics" and "Informatics, robotics and de- } \\
\text { sign". On January } 20 \text {, first-year students of these pro- } \\
\text { grams began to study the disciplines of "Educational } \\
\text { Robotics". }\end{array}$ & $\begin{array}{l}\text { The training is provided } \\
\text { both by the academists } \\
\text { and the Ozat teachers } \\
\text { during practical classes. }\end{array}$ \\
\hline
\end{tabular}

In the organization of practice-oriented training, universities recommend using the following methods of its implementation:

1. Strengthen the block of practices (increase the amount of study time allocated to educational, industrial, research and undergraduate practice).

2. Involve specialists, leading professionals in the educational process in the university: teachers-mentors, teachers-innovators in the relevant subject areas.

3. Apply innovative teaching technologies, that include the solution of students' professional problems in course of their theoretical training.

4. Increase awareness of the chosen profession and its significance.

Involve students in innovative forms of work on the solution of scientific and practical tasks within the framework of student scientific societies, business incubators, research and production associations, etc.

\section{Discussion}

The process of introducing dual education has been going on for several years in Kazakhstan. In addition to the state, the business community is actively involved in it. This is driven by the needs of the business itself, which is in dire need of up-to-date skilled personnel. To get them, businesses provide universities with training for their staff and technical facilities. During the years of the dual education program, a certain number of positive results have been achieved. The order of recruitment of young 
professionals has changed in the regions. In general, the country's personnel reserve is now experiencing an influx of fresh forces.

Processes of dualization learning are carried out in modern educational environments, characterized by tendencies towards unification under the influence of informatization and globalization, which leads to the introduction of the concept of "integrative macroenvironment of vocational education". The conceptual model of an integrative vocational education macroenvironment includes levels of integration, components and properties of the environment, its functions in self-development, as well as variational vocational-developmental resources. The integration occurs at the methodological, structural and functional, substantive levels (Table 7).

Table 7. Components of conceptual model

\begin{tabular}{|c|c|c|c|}
\hline Level & \multicolumn{3}{|c|}{ Components } \\
\hline Methodological & \multicolumn{3}{|c|}{$\begin{array}{l}\text { Synthesis of systemic, synergetic, personality-activity, ecological- } \\
\text { psychological, competence approaches }\end{array}$} \\
\hline Structural and functional & $\begin{array}{l}\text { The micro environ- } \\
\text { ment of individual } \\
\text { educational organi- } \\
\text { zations and their } \\
\text { structural units. }\end{array}$ & $\begin{array}{l}\text { The meso environment } \\
\text { of general, professional } \\
\text { and additional education. }\end{array}$ & $\begin{array}{l}\text { The macro environment as an } \\
\text { open global system where } \\
\text { subsystems exchange infor- } \\
\text { mation and resources are } \\
\text { transformed under the influ- } \\
\text { ence of integration processes. }\end{array}$ \\
\hline Substantive & \multicolumn{3}{|c|}{$\begin{array}{l}\text { Association of varied professional development resources, relationships be- } \\
\text { tween which are cooperative. }\end{array}$} \\
\hline
\end{tabular}

It is important to remember that the modern macroenvironment integrates the educational resources of general, professional and additional education. Dedicated subsystems are integrated within their functional purpose. Internal links connect the subsystems and resources of an educational environment into a single system. In order to successfully develop professional skills while introducing dual education in higher educational institutions of Kazakhstan it is necessary to adhere to the principles of formation of the structure and content of the educational program (Figure 1). 

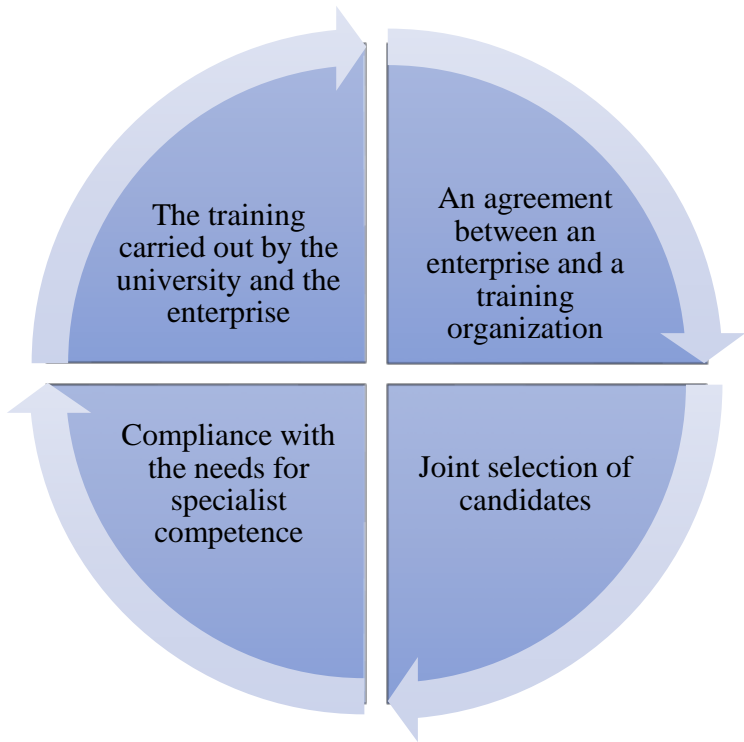

Fig. 1. Principles of formation of the structure and content of the educational program

The structure of the integrative macro-environment of vocational education contains material, technical, content-methodical and social-communicative components. The material and technical components are a set of substantive and material conditions of the environment. The content-methodical component includes technological mechanisms for creating conditions for the dualization of education. The socialcommunicative component defines the interaction of the subjects of the educational process and the management aspects of the organization of dual learning.

The integrative macro vocational education environment is characterized by the properties of integrativeness, discretion, hierarchy, integrity, variability, intensity.

Dual education in the conditions of an integrative vocational education macroenvironment is based on the implementation of the principles of continuity, integrity, systematicity, variability, resource availability of the environment. System-forming principle is the principle of continuity, which allows you to consider the development throughout life. As a result of the introduction of the dual system, such indicators of professional skills of a specialist will increase (Figure 2). 
Paper-Development of Professional Skills in the Context of Higher School Dual Education

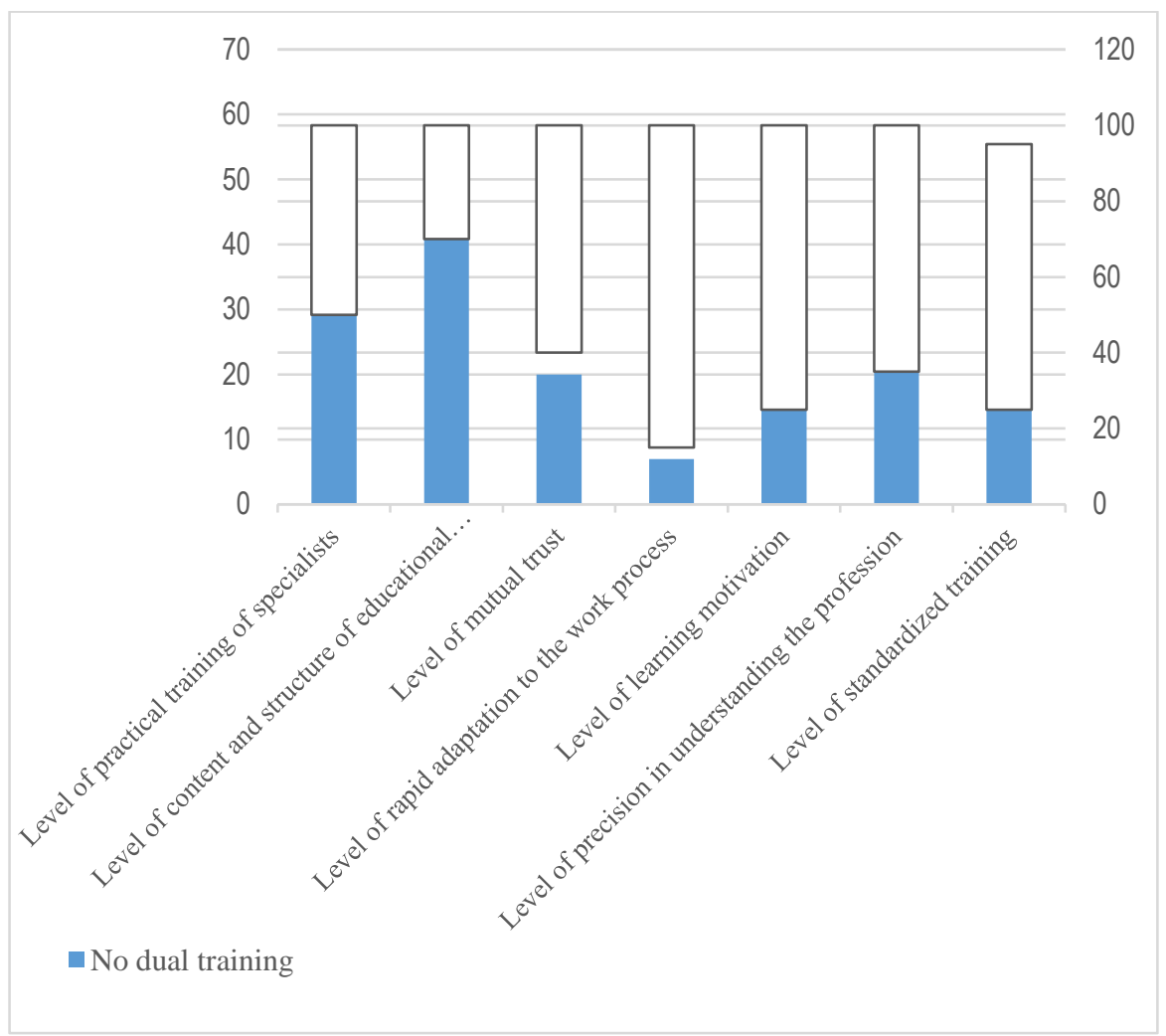

Fig. 2. Increasing indicators of professional skills

The chart shows indicators of professional skills development before and after engaging students in the production process (Figure 3).

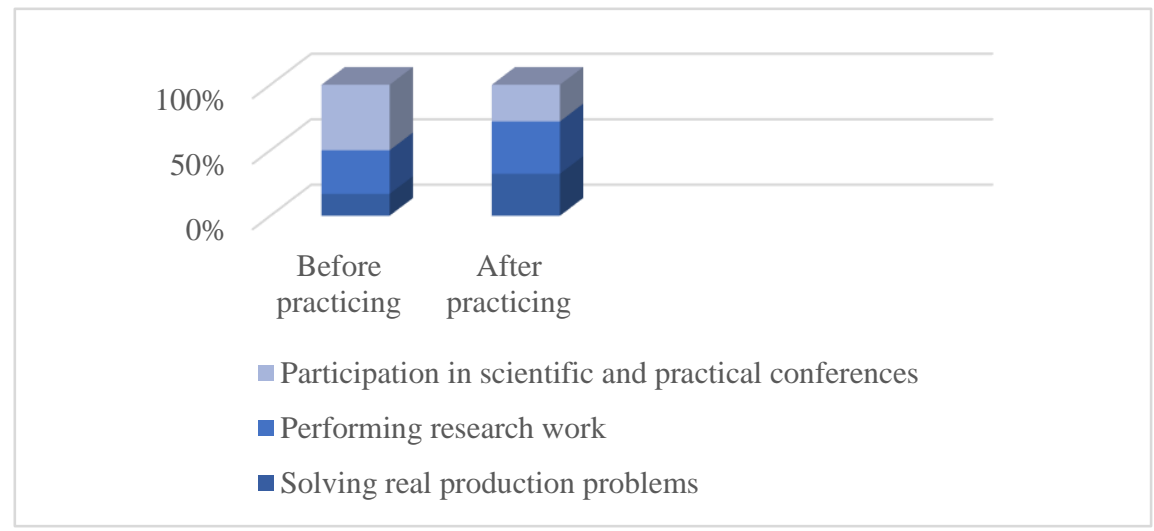

Fig. 3. Indicators of professional skills development 
As a result of passing industrial practice in the system of dual education, the student must acquire the following professional skills:

- Readiness for communication, teamwork, cooperation with colleagues

- Ability to find effective solutions of organizational and managerial issues in nonstandard situations and willingness to be responsible for them

- Ability to use current legal normative documents in the field of profession

- Willingness to show respect for another culture, to moral and legal norms of society, responsibility for maintaining partnership, trusting relationships

- Ability to use scientific knowledge in solving practical problems arising in course of professional activity

- Mastery of basic technologies, methods of finishing and development of technological processes

- Ability to organize production quality control and documentation

- Applying methods of quality control of technological processes in production

- Readiness for organization of workplaces, selection of their technical equipment, proper placement of technological equipment

- Ability to monitor compliance with technological discipline and eco-safety

- Ability to freely choose types and forms of activity, free pricing policy

- Competitiveness of market entities with different forms of ownership

- Self-regulation of economic activity

- Economic compliance

- Self-financing

- The principle of contractual relations

The collaboration of higher education institutions and enterprises in the implementation of dual-technology training should be based on the competences that will be produced for the student as a result of the internship (Figure 4).

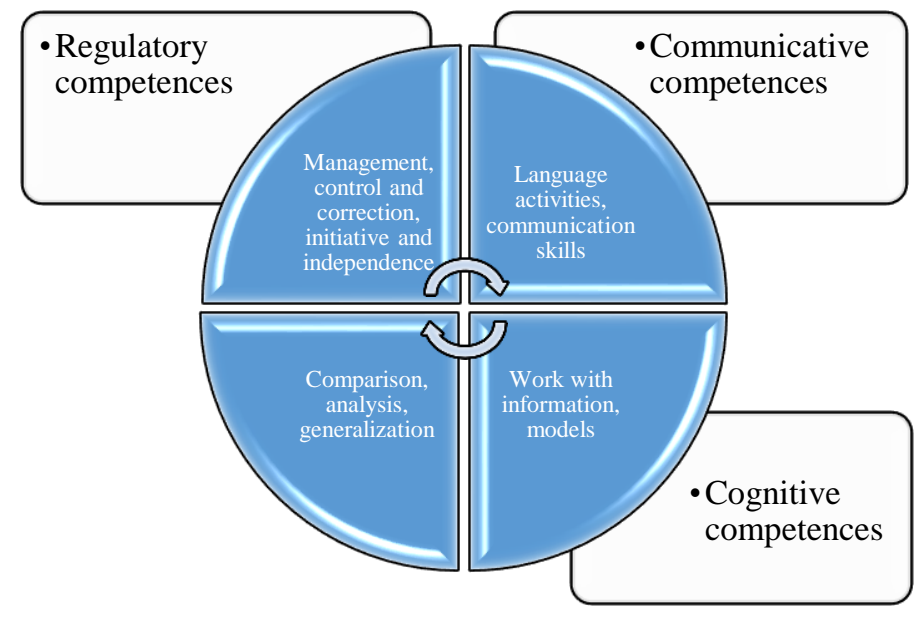

Fig. 4. The main practical competences 
In order to create an integrated macro vocational education environment, it is necessary to make a classification of the varied professional-developmental resources of an integrative macro vocational education environment, which includes:

1. Program-technical resources (technical and related software tools to support the educational process and its automation, as well as the continuous development of information and technical infrastructure of the environment).

2. Informational-educational resources (single educational environment: search and reference systems, educational portals, electronic libraries, simulators, training programs, multimedia tools and other electronic resources).

3. Social-communicative resources (creating an educational network, integrating telecommunication resources and network communities to facilitate interaction between participants of the educational process).

4. Scientific-methodological resources (opportunities for participation in conferences, symposia, seminars; advanced training in distance learning).

\section{Conclusion}

The conducted research allows to formulate a conclusion about the determinative influence of the integrative macro environment of vocational education on the dualization of education. Such macro environment is characterized by integrativeness, discretion, hierarchy, integrity, variability and intensity. Its conceptual model involves the synthesis of systemic, synergetic, personality-activity, ecological-psychological, competence approaches, as well as varied professional development resources which demonstrate its integration at the methodological, structural, functional, and substantive levels. The implementation of dual system in the universities is based on strengthening the block of practices, involving specialists, applying innovative teaching technologies, increasing professional awareness of the students and involving them in the solution of scientific and practical tasks. The positive effects of such implementation are substantial improvement of the practical training of specialists, the content and structure of educational programs, increasing mutual trust, better adaptation to the work process, increasing learning motivation, and precision in understanding the profession, and the quality of standardized training. Prospects for further research are related to the generalization of the results obtained, and their implementation in the practice of educational organizations.

\section{References}

[1] Dudukalov, E. V. (2013). Conditions for economic growth at the stage of post-industrial transformation of the world economy. Gosudarstvennoye i munitsipal'noye upravleniye. Uchenyye zapiski SKAGS, 3, 89-94. Available at: https://cyberleninka.ru/article/n/usloviy a-ekonomicheskogo-rosta-na-etape-postindustrialnoy-transformatsii-mirovoy-ekonomiki/p df. 
[2] Sabirova, F., Vinogradova, M., Isaeva, A., Litvinova, T., \& Kudinov, S. (2020). Professional Competences in STEM Education. International Journal of Emerging Technologies in Learning (iJET), 15(14), 179-193. https://doi.org/10.3991/ijet.v15i14.13527

[3] Tleubay, S., Nurzhanova, G., Ybyshova, S., Abdigulova, S., Mankesh, A., Kerimbekov, T., \& Ualikhanuly, A. (2020). The Formation of Intercultural Communicative Competence of Future Teachers in a Trilingual Educational Environment. International Journal of Emerging Technologies in Learning (iJET), 15(17), 148-164. https://doi.org/10.3991/ijet. v15i17.14249

[4] OECD: Knowledge Management in the Learning Society (2000). Paris: OECD Publishing. https://doi.org/10.1787/9789264181045-en

[5] Hermann, F., Korunka, C., Lueger, M., \& Weismeier-Sammer, D. (2016). Intrapreneurship education in the dual education system. International Journal of Entrepreneurial Venturing, 8(4), 334-354. https://doi.org/10.1504/ijev.2016.10001847

[6] Bakator, M., Borić, S., Radosav, D., \& Radić, G. (2017). Innovative model of dual education through student-organization networks [Electronic version]. In ITRO 2017. June 2017, Zrenjanin, Republic of Serbia (pp. 253-257). Retrieved from https://www.researchgate. net/profile/Mihalj_Bakator/publication/333386013_Innovative_model_of_dual_education_ through_student-organization_networks/links/5cea5bfc458515712ec357fe/Innovative-mo del-of-dual-education-through-student-organization-networks.pdf. https://doi.org/10.1002/ yd. 20250

[7] Oganisjana, K., Svirina, A., Surikova, S., Grīnberga-Zālīte, G., \& Kozlovskis, K. (2017). Engaging universities in social innovation research for understanding sustainability issues. Entrepreneurship and Sustainability Issues, 5(1), 9-22. https://doi.org/10.9770/jesi.2017.5. $\underline{1(1)}$

[8] Gessler, M., \& Peters, S. (2017). Implementation of dual training programmes through the development of boundary objects: A case study. Educar, 53(2), 309-331. http://dx.doi.org/ $10.5565 /$ rev/educar.862

[9] Goeke, J. L., Mitchem, K. J., \& Kossar, K. R. (Eds.). (2017). Redesigning special education teacher preparation: Challenges and solutions. New York: Routledge. https://doi.org/ $\underline{10.4324 / 9781315518459}$

[10] Galustyan, O. V., Kirik, V. A., \& Mazáčová, N. (2019). Partnership of University and Schools within the Preparation of Future Teachers. International Journal of Emerging Technologies in Learning, (iJET), 14(17), 153-161. https://doi.org/10.3991/ijet.v14i17.108 $\underline{29}$

[11] Spasenović, V. (2017). The dual education system: implementation possibilities, prerequisites and challenges. Nastava i vaspitanje, 66(3), 411-421. https://doi.org/10.5937/nasvas $\underline{1703411 \mathrm{~s}}$

[12] Valiente, O., \& Scandurra, R. (2017). Challenges to the implementation of dual apprenticenships in OECD countries: A literature review. Vocational education and training in times of economic crisis (pp. 41-57). Springer, Cham. Available at: https://www.researchgate.net/profile/Matthias Pilz/publication/321540139 Vocational Ed ucation_and_Training_in_Times_of_Economic_Crisis_Lessons_from_Around_the_World /links/5bc499d1a6fdcc2c91fc4ab0/Vocational-Education-and-Training-in-Times-of-Econo mic-Crisis-Lessons-from-Around-the-World.pdf\#page=63. https://doi.org/10.1007/978-3319-47856-2

[13] Azevedo, F. S. (2018). An inquiry into the structure of situational interests. Science Education, 102(1), 108-127. https://doi.org/10.1002/sce.21319

[14] Bogdanović, M., Vetráková, M., \& Filip, S. (2018). Dark triad characteristics between economics \& business students in Croatia \& Slovakia: what can be expected from the fu- 
ture employees? Entrepreneurship and Sustainability Issues, 5(4), 967-991. https://doi.org/ $\underline{10.9770 / j e s i .2018 .5 .4(19)}$

[15] Boroš, M., Vel'as, A., Kampová, K., \& Loveček, T. (2018). Creation of final works as part of the dual education of university graduates. Edulearn 18. 10th International Conference on Education and New Learning Technology (Palma, 2nd-4th of July, 2018): conference proceedings (pp. 6710-6713). IATED Academy. https://doi.org/10.21125/edulearn.2018. 1591

[16] Alajmi, M. M. (2019). The impact of E-portfolio use on the development of professional standards and life skills of students: A case study. Entrepreneurship and Sustainability Issues, 6(4), 1714-1735. https://doi.org/10.9770/jesi.2019.6.4(12)

[17] Darling-Hammond, L., Flook, L., Cook-Harvey, C., Barron, B., \& Osher, D. (2020). Implications for educational practice of the science of learning and development. Applied Developmental Science, 24(2), 97-140. https://doi.org/10.1080/10888691.2018.1537791

[18] Didukh, L., Gurevych, R., Kademija, M., \& Kobysia, V. (2019). Experience of preparation of competitive specialists in the conditions of the implementation of dual education in high education institution. Scientific Journal of Polonia University, 33(2), 129-135. https://doi. org/10.23856/3314

[19] Kulalaieva, N., \& Leu, S. (2019). Work-based learning involving the dual education elements. Professional Pedagogics, 1(18), 162-168. https://doi.org/10.32835/2223-5752.20 19.18.162-168

[20] Wichitsathian, S., \& Nakruang, D. (2019). Knowledge integration capability and entrepreneurial orientation: case of Pakthongchai Silk Groups Residing. Entrepreneurship and Sustainability Issues, 7(2), 977-989. https://doi.org/10.9770/jesi.2019.7.2(13)

[21] Pogatsnik, M. (2018). Dual Education: The win-win model of collaboration between universities and industry. International Journal of Engineering Pedagogy (iJEP), 8(3), 145152. https://doi.org/10.3991/ijep.v8i3.8111

[22] Hahn, K. H., \& Puksas, A. (2018). Factors influencing student entrepreneurship intentions: the case of Lithuanian and South Korean universities. Entrepreneurship and Sustainability Issues, 6(2), 854-871. https://doi.org/10.9770/jesi.2018.6.2(26)

[23] Belas, J., Gavurova, B., Čepel, M., \& Kotaskova, A. (2018). Relationship of gender to the position of Slovak University students on the socio-economic determinants of the business environment and the development of entrepreneurship. Entrepreneurship and Sustainability Issues, 8(2), 968-978. https://doi.org/10.9770/jesi.2018.6.2(33)

[24] Fatoki, O. (2019). Sustainability orientation and sustainable entrepreneurial intentions of university students in South Africa. Entrepreneurship and Sustainability Issues, 7(2), 990999. https://doi.org/10.9770/jesi.2019.7.2(14)

[25] Order of the Minister of Education and Science of the Republic of Kazakhstan dated January 21, 2016 No. 50. (2018). On the approval of the Rules for the organization of dual training (as amended on September 11, 2018). Available at: https://online.zakon.kz/Docu ment/?doc id=36492538 [Accessed September 20, 2020]

[26] Dudukalov, E. V., \& Laptander, A. B. (2015). Education and science: how to continue the modernization during recession? Nauka i Obrazovaniye: Khozyaystvo i Ekonomika; Predprinimatel'stvo; Pravo i Upravleniye, 1, 7-13. Available at: http://journal-nio.com/ima ges/pdf2017/2016/2015/1_56.pdf

[27] National ranking of the best universities of Kazakhstan IQUAA-2019. (2019). Electronic government of the Republic of Kazakhstan. Available at: https://egov.kz/cms/ru/articles/ 2Fbestuniinkz30 [Accessed September 20, 2020]

[28] Decree of the Government of the Republic of Kazakhstan dated December 27, 2019 No. 988 "On approval of the State program for the development of education and science of the 


\section{Authors}

Nursaule Tastanbekova (https://orcid.org/0000-0002-5568-8418) is a senior lecturer at the S. Seifullin Kazakh Agro Technical University, Department of Computer Systems and Vocational Training, the Department of Vocational Education. She is a graduate student of the S. Seifullin Kazakh Agro Technical University, Republic of Kazakhstan, 010011, Nur-Sultan, 62, Zhenis Avenue.

Bahyt Abenova is a senior lecturer at the S. Seifullin Kazakh Agro Technical University, Department of Computer Systems and Vocational Training, the Department of Vocational Education. She is PhD, Candidate of the Pedagogical Science. Republic of Kazakhstan, 010011, Nur-Sultan, 62, Zhenis Avenue.

Maral Yessekeshova is $\mathrm{PhD}$, Candidate of the Pedagogical Science, an associate professor at the S. Seifullin Kazakh Agro Technical University, Department of Computer Systems and Vocational Training, the Department of Vocational Education. She is a head of the Department of Professional Education of the S. Seifullin Kazakh Agro Technical University, Republic of Kazakhstan, 010011, Nur-Sultan, 62, Zhenis Avenue.

Zhanar Sagaliyeva is a senior lecturer at the S. Seifullin Kazakh Agro Technical University, Department of Computer Systems and Vocational Training, the Department of Vocational Education. She is PhD, Candidate of the Pedagogical Science. Republic of Kazakhstan, 010011, Nur-Sultan, 62, Zhenis Avenue.

Gulmira Abildina is a senior lecturer at the S. Seifullin Kazakh Agro Technical University, Department of Computer Systems and Vocational Training, the Department of Physics and Chemistry. She is PhD, Candidate of the Chemical Sciences. Republic of Kazakhstan, 010011, Nur-Sultan, 62, Zhenis Avenue.

Article submitted 2020-10-21. Resubmitted 2020-11-27. Final acceptance 2020-11-28. Final version published as submitted by the authors. 